\title{
Wasteland and Empty Plots Trivialization in the Maradi City (Niger): Between Environmental Degradation and Consequent Nuisance, Quality of life and Sustainability of Biodiversity
}

\author{
Karimou Dia Hantchi1 ${ }^{*}$, Oumarou Zango², Amadou Oumarou ${ }^{3}$, Boubé Morou ${ }^{4}, M^{2}$ (ssa Konaté5 \\ ${ }^{1}$ Department of Geology, Faculty of Science and Techniques, Dan Dicko Dankoulodo University, Maradi, Niger \\ ${ }^{2}$ Department of Chemical and Biological Sciences, Faculty of Science and Techniques, University of Zinder, Zinder, Niger \\ ${ }^{3}$ Department of Medicine, Faculty of Health Science, Dan Dicko Dankoulodo University, Maradi, Niger \\ ${ }^{4}$ Department of Biology, Faculty of Science and Techniques, Dan Dicko Dankoulodo University, Maradi, Niger \\ ${ }^{5}$ Department of Geology, Faculty of Science and Techniques, Abdou Moumouni University, Niamey, Niger \\ Email:*zangooumarou@gmail.com
}

How to cite this paper: Hantchi, K.D., Zango, O., Oumarou, A., Morou, B. and Konaté, M. (2022) Wasteland and Empty Plots Trivialization in the Maradi City (Niger): Between Environmental Degradation and Consequent Nuisance, Quality of life and Sustainability of Biodiversity. Occupational Diseases and Environmental Medicine, 10, 13-34.

https://doi.org/10.4236/odem.2022.101002

Received: October 28, 2021

Accepted: January 1, 2022

Published: January 4, 2022

Copyright $\odot 2022$ by author(s) and Scientific Research Publishing Inc. This work is licensed under the Creative Commons Attribution International License (CC BY 4.0).

http://creativecommons.org/licenses/by/4.0/ (c) (i) Open Access

\begin{abstract}
The trivialization of empty spaces has long been practiced in the city of Maradi (Niger), particularly in the Zaria 2 (Commune II) and Ali Dan Sofo (Commune III) districts. With stalls in the streets and illegal dumping grounds, empty plots and the surrounding areas are fairly privileged sources of various wastes. This study aims at analyzing the impact of these empty plots on the local population, through several aspects, especially in terms of the modes of occupation, internal and surrounding practices, physical environment and biodiversity, sanitation and elimination of waste. To do so, two methodological approaches were used: a survey on local population and in situ observation of these spaces. The results not only reveal a difficult proximity situation to the unbuilt but also showed that empty plots constitute not only a form of vegetation conservation for the future as well as clean surfaces which would be called upon to characterize the potential recharge of groundwater. The most potentially useful organic waste would be that of Kadro, especially feathers from poultry that could be used as compost in the fields. In addition to the degradation of urban environments (63\% of respondents), the unbuilt area also contributes to poverty reduction and increases food security (69\% of respondents). To reduce the negative impacts, the rewarding strategies would be awareness-raising and monitoring measures coupled with a policy of protection and environmental remedies.
\end{abstract}




\section{Keywords}

Urban Environment, Empty Plots, Biodiversity, Waste Impacts, Maradi, Niger

\section{Introduction}

Urban population growth causes the development of the city based on a distant spread of urbanization [1]. Increase in population appears as one of the major modernization processes, and persevering development of specific activity sectors around and in the city [2]. At its best, it promotes new infrastructures on the periphery and abandonment of land in areas located at the city center [3]. However, it is also the production of bulky waste on good land, exacerbating environmental degradation and increasing the vulnerability of habitats to natural hazards [4] [5]. Some studies even specify that the ephemeral nature of the empty spaces creates a massive diffusion and exhibition and the usefulness of biodiversity in cities [6] [7] [8].

In Niger, the critical situation regarding life quality in urban areas highlights the acute problem of managing waste produced in cities [9]. This problem can be observed in almost all the streets of the big cities, which are often infested with too much waste of all kinds [10] [11]. In the same vein, a whole range of landscape trivialization has emerged, creating an alarming situation regarding the balance of the urban ecosystem [12]. However, in Niger, there are quite a number of legislative and regulatory texts and Niger seems to be ahead of many West African countries [13]. An example is the Framework law 98-56 of 29 December 1998 on environmental management [14]. This law recalls, for example, in its article (Art. 27) that "It is forbidden to deposit household waste, stones, gravel, wood, industrial waste in the bed or on the banks of rivers, lakes, ponds or lagoons and canals of the public domain. It is also forbidden to let water whether infected or harmful, to run out". In addition, Section 5 (Art. 64) states that "decentralized local authorities shall ensure the disposal of household waste, excreta, wastewater and other related waste throughout their territory in collaboration with public or private sanitation services". What matters from this point of view is the practical implementation of strategies, i.e., the effective urban planning scheme that arises with enormous difficulties [15].

The case of the city of Maradi is quite typical. Being the economic capital of Niger [16], Maradi is indisputably a city that attracts a lot of people. This attractiveness is mainly linked to the countless markets and commercial hubs that operate seven days a week. People migrate to Maradi due to job opportunities that, large construction sites offer [17]. Maradi is also and above all the town of " $E I$ hazai,"'the rich people" who represent the city business owners as well as landlords. For these individuals, land is an object of commercial speculation, in addition to it being an inheritance for their offspring. Thus, the "Elhazai" and their heirs exert an influence on the city center by promoting the emergence of large 
unbuilt estates in anticipation of more interesting auction [18]. This means that the waste from all these activities generates considerable heap of waste, which increases as we approach the shopping malls markets and empty spaces [19].

Previous works [20] [21] [22] [23] [24] have shown that laws and regulations are taken mainly to address prevailing corruption. Indeed, some believe that the state services are themselves troublemakers because they are more concerned with immediate interests to meet their own needs in maintaining their way of life in a healthy state. So, a kind of expectation and resignation prevails among the population. Ultimately, estimating the intensity of contact between biological diversity and agents present in different environments is a difficult task. It would be desirable, according to the above-mentioned authors, that local authorities should be able to improve their methods in order to avoid all possible consequences, including soil contamination. Finally, we should mention local knowledge which, according to some authors, is another important bias to be discussed in the process of identifying urban problems. However, very little attention has been paid so far to the environmental and landscape issues posed by empty plots.

The present study aims at contributing to a better understanding of the environmental issues related to the presence of empty spaces, sometimes transformed into uncontrolled waste depots, in the urban fabric of the city of Maradi (Niger). The research seeks to tackle the following s points: 1) identifying forms of occupancy of space on vacant land, 2) specifying the positive and negative environmental impacts on the living environment, and finally 3) proposing technical and regulatory developments to reinforce the positive consequences and limit the problems linked to these empty plots.

\section{Material and Methods}

\subsection{Study Areas Description}

The city of Maradi is located in the southern center part of Niger about $645 \mathrm{~km}$ from the capital Niamey (Figure 1(A)). It is between latitudes 13.46857 and 15.53267 degrees North and longitudes 7.07737 and 7.12847-degrees Est (Figure 1(B); coordinates are in decimal degrees). In 2016, Maradi Urban Community had 313,209 inhabitants living on an area of $86 \mathrm{~km}^{2}$ [16]. The urban administrative make up consists of 17 districts divided into three communes that are Maradi 1, 2 and 3 (Figure 1(B); [23]). Located on a plateau with an average altitude of $380 \mathrm{~m}$, the city of Maradi runs along the right bank of the Goulbi Maradi, the main river draining the region and the surrounding area of the city to the west [19]. On the north side of the city lie cliffs with steep slopes. To the east and south, the city is bounded by plains on which agricultural crops are grown [25]. The other dynamic framework for activities in Maradi is handicrafts and rural exodus, which contribute significantly to the city's economy [26]. But the city of Maradi is best known for its commercial activity, in terms of the number of markets, streets lined with shops and street vendors that are found in the different 


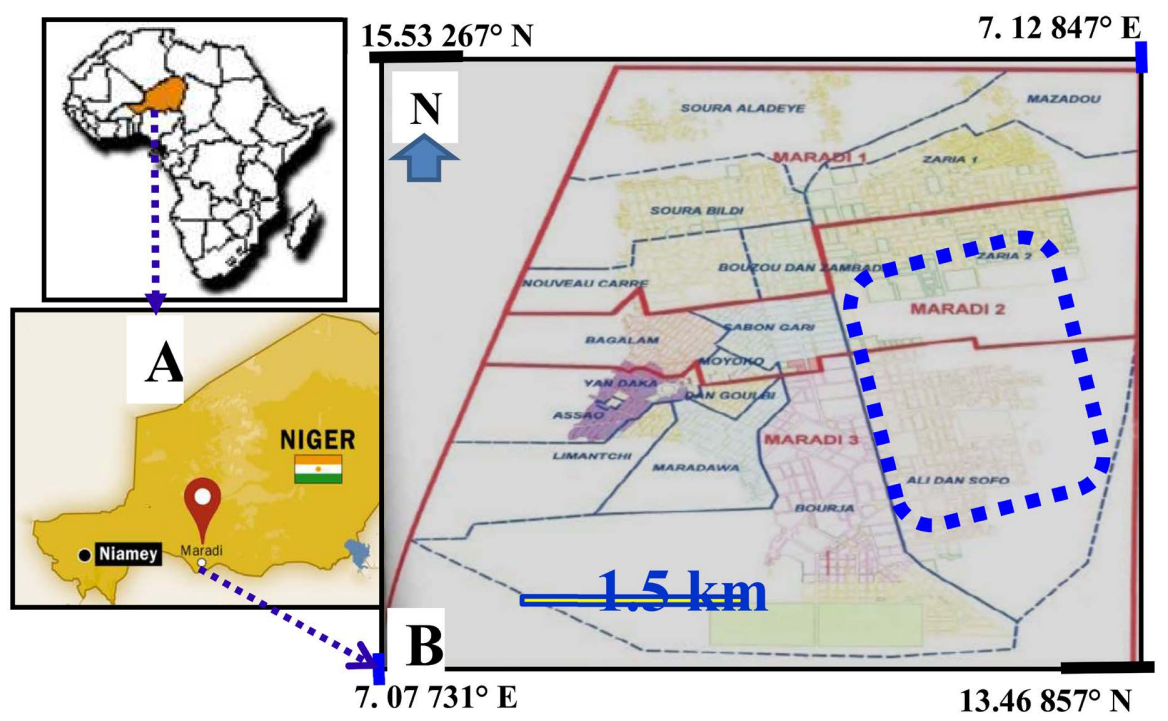

Figure 1. Location map (A) and administrative organization of Maradi City ((B); [23]). The blue rectangular box constitutes the framing of study sites.

districts of this city [17].

\subsection{Sampling Methodology and Data Collection}

The methodological approach used is divided into five stages. First, there is the summary survey, then sampling, the design of information collection tools, field observations and the questionnaire survey. The summary investigation collected more or less general information. Thus, field visits were carried out to see the living environment of the people in the three municipalities of Maradi. Subsequently, a series of discussions and exchanges were held with key informants and workers at the mayor's office of Maradi. The aim was to identify the gaps or lack of information that the study should attempt to address. To build up the neighborhood sample, Google Earth data was used to better identify the important bushes in empty spaces. Thus, for their proportion in empty plots, in addition to their socio-economic dynamism, two districts of two Maradi municipalities were chosen, which are Zaria 2 (Maradi 2) and Ali Dan Sofo (Maradi 3) (Figure 1(B)).

Strategic observations provided a general overview of the extent of the unsanitary nature of our study environment and identified areas most likely to provide answers to some questions related to empty spaces (Figure 1 and Figure 2). These include the surroundings of the Malam Hamissou Dan Taxi (box A: MHDT), the King Plazza and Dan Dicko Dankoulodo and Maryam Abacha American Universities (box B), and the box C for the Kadro Market and Maradi Airport surroundings (Figure 2).

The questionnaire collected information from the public. It targeted households and traders in those areas. As we can see in Table 1, we can loosely divide the field into two groups: 1) those sympathetic, core group leaders, who are turning housing or commercial activities into empty plots and merchants committed 


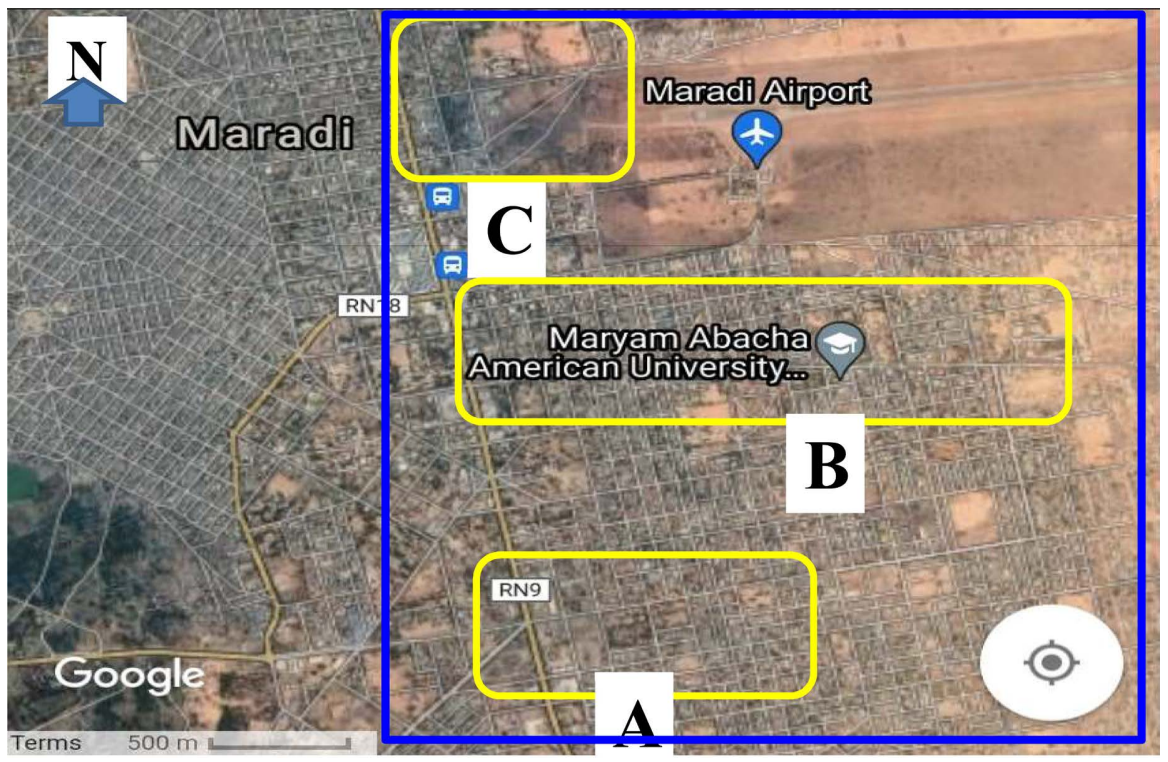

Figure 2. Location of the random sampling areas (blue box). Box A: MHDT Mosque area. Box B: Maryam Abacha Amercian University. Box C: East Kadro Market and West Maradi Airport surroundings (Source: Google Earth).

Table 1. Activities of support and opposition of empty and wasteland plots and participatory criteria format.

\begin{tabular}{ccc}
\hline Group & Activities & Survey Important Criteria \\
\hline & $\begin{array}{c}\text { Internal housing or Commercial } \\
\text { activities }\end{array}$ & $\begin{array}{c}\text { Core group leaders/Identified groups } \\
\text { and Interested individuals }\end{array}$ \\
& $\begin{array}{c}\text { Commercial activities outside or } \\
\text { beside }\end{array}$ & Interested individuals \\
\hline Unsympathetic & Neighbor households & Interested individuals \\
\hline
\end{tabular}

to the exclusive anchoring in the proximity space of their activities in the empty space, 2) and households, unsympathetic to their "proximity to empty spaces". All study participants signed a consent form, and data were collected through interviews anonymously [27]. To prevent an impact on the representativeness of the respondent numbers, a team of core group leaders were contracted to enthusiastically work with small groups and coalitions. The core group leaders were supportive in general, though the extent of that support may be unclear [28]. It should be noted that semi-direct maintenance was used to gather information on the negative and positive impacts of empty plots and on the wild occupation of adjoining spaces. This questionnaire covered activities of concern to them, their knowledge of vegetation and urban fauna, the risks posed by waste deposits, diseases caused by garbage, the harms of the proliferation of garbage on the environment and the mitigation measures to be proposed.

The sample of respondents was randomly selected based on the total number of people found at the sites. In total, of all genders, the study involved a sample of thirty-six (36) people (i.e., core group leaders into empty plots, sympathetic 
traders and unsympathetic households): sixteen of whom were in Ali Dan Sofo and twenty in Zaria 2 (Around East Kadro Market). The equipment used included survey files and a GPS to locate the sites (Table 2) a camera to take photographs (Figures 3-5). The response rate at the respondent level by parameters was calculated using the formula of [29]. It is determined by the following formula $F=S / N \times 100$, with $F$ the response rate for the type of parameters (\%), $S$

Table 2. Geographic coordinates of random sampling stations.

\begin{tabular}{|c|c|}
\hline Zone & Deposits samples created (Latitude; Longitude) \\
\hline \multirow{9}{*}{$\begin{array}{l}\text { A: } \\
\text { Malam Hamissou Dan Taxi (MHDT) } \\
\text { Residence (A1) } \\
\text { andMosque (A2) }\end{array}$} & Ala: Empty plot A1 center $\left(13.47862^{\circ} \mathrm{N} ; 7.11591^{\circ} \mathrm{E}\right)$ \\
\hline & A1b: Empty plot A1 North-West corner $\left(13.47886^{\circ} \mathrm{N} ; 7.11547^{\circ} \mathrm{E}\right)$ \\
\hline & A1c: Empty plot A1 North-East corner $\left(13.47896^{\circ} \mathrm{N} ; 7.11632^{\circ} \mathrm{E}\right)$ \\
\hline & A2a: Heavy Trucks Parking lot $\left(13.47989^{\circ} \mathrm{N} ; 7.11458^{\circ} \mathrm{E}\right)$ \\
\hline & A2b: Southern (a) and northern (b) parts of an access road to an Elementary school (ES) \\
\hline & and the eastern wall of the Parking lot $\left(13.48129^{\circ} \mathrm{N} ; 7.11490^{\circ} \mathrm{E}\right)$ \\
\hline & A2c: Municipal dump (East A2P and southern A2ESP) $\left(13.47957^{\circ} \mathrm{N} ; 7.11526^{\circ} \mathrm{E}\right)$ \\
\hline & A2d: Heavy Trucks Parking (Northern of the wall) $\left(13.48168^{\circ} \mathrm{N} ; 7.11478^{\circ} \mathrm{E}\right)$ \\
\hline & A2e: Heavy Trucks Parking (Western of the wall) $\left(13.48051^{\circ} \mathrm{N} ; 7.11381^{\circ} \mathrm{E}\right)$ \\
\hline \multirow{6}{*}{$\begin{array}{l}\text { B: } \\
\text { Dan Dicko Dankoulodo University } \\
\text { (B1-2), } \\
\text { KSG Plazza and Maryam Abacha } \\
\text { American University (B3) }\end{array}$} & B1a: Mourna Market Empty plot $\left(13.49206^{\circ} \mathrm{N} ; 7.12722^{\circ} \mathrm{E}\right)$ \\
\hline & B1b: North Mourna Market Empty plot (South 20 Villas) $\left(13.49261^{\circ} \mathrm{N} ; 7.12726^{\circ} \mathrm{E}\right)$ \\
\hline & B2a: CARE Maradi Empty plot (West side) $\left(13.49197^{\circ} \mathrm{N} ; 7.12629^{\circ} \mathrm{E}\right)$ \\
\hline & B2b: CARE Maradi Empty plot (East side) $\left(13.49208^{\circ} \mathrm{N} ; 7.12597^{\circ} \mathrm{E}\right)$ \\
\hline & B3a: KSG Plazza/Elementary School $\left(13.49182^{\circ} \mathrm{N} ; 7.12413^{\circ} \mathrm{E}\right)$ \\
\hline & B3b: Maryam Abacha University $\left(13.49202^{\circ} \mathrm{N} ; 7.12231^{\circ} \mathrm{E}\right)$ \\
\hline \multirow{2}{*}{$\begin{array}{l}\text { C: } \\
\text { Kadro Market and Maradi Airport } \\
\text { neighborhoods }\end{array}$} & C2a: Kassuar Kadro deposit $\left(13.49900^{\circ} \mathrm{N} ; 7.11061^{\circ} \mathrm{E}\right)$ \\
\hline & C2b: Kassuar Kadro Deposit $\left(13.50136^{\circ} \mathrm{N} ; 7^{\left.11269^{\circ} \mathrm{E}\right)}\right.$ \\
\hline
\end{tabular}

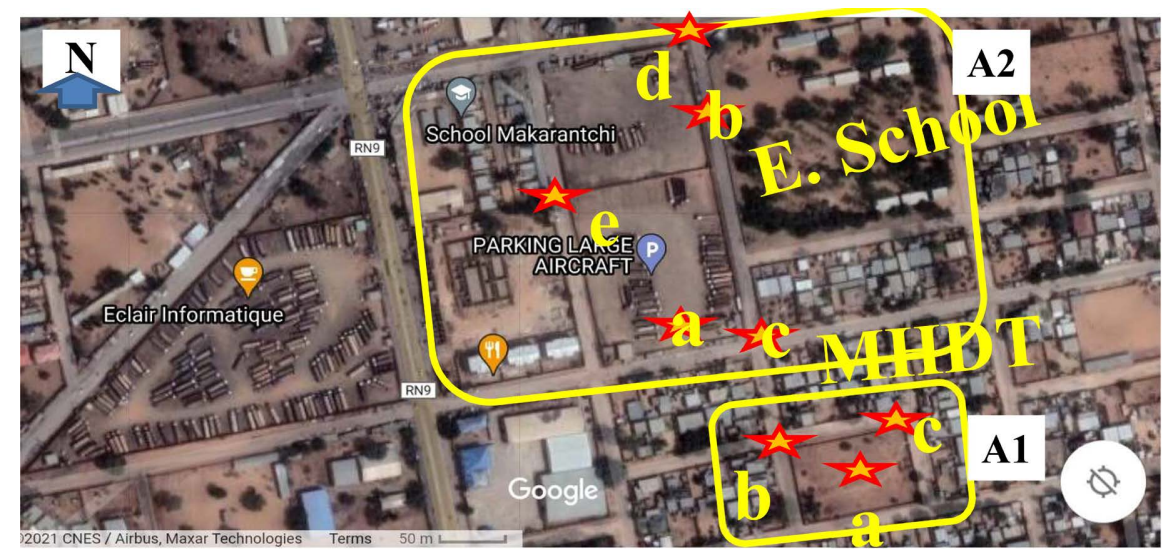

Figure 3. Random sampling area and geographical location of the photos used in the site A. (A1) and (A2) constitute our sample for Malam Hamissou Dan Taxi (MHDT) residence and Mosque (Elementary school and Parking large aircraft areas), respectively (Source: Google Earth). 


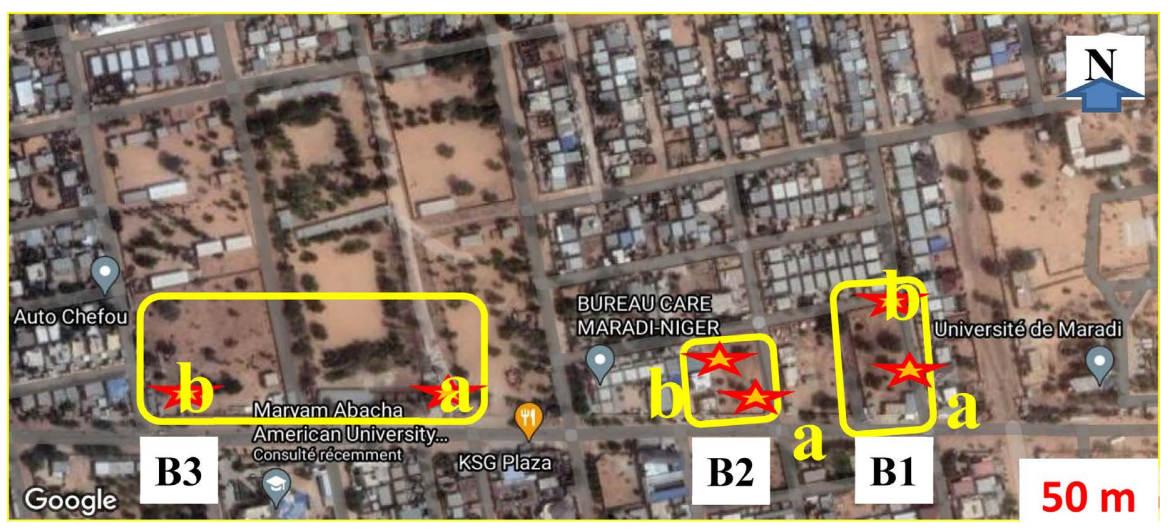

Figure 4. Random sampling area and geographical location of the photos (red yellow stars) used in the site (B) (Source: Google Earth).

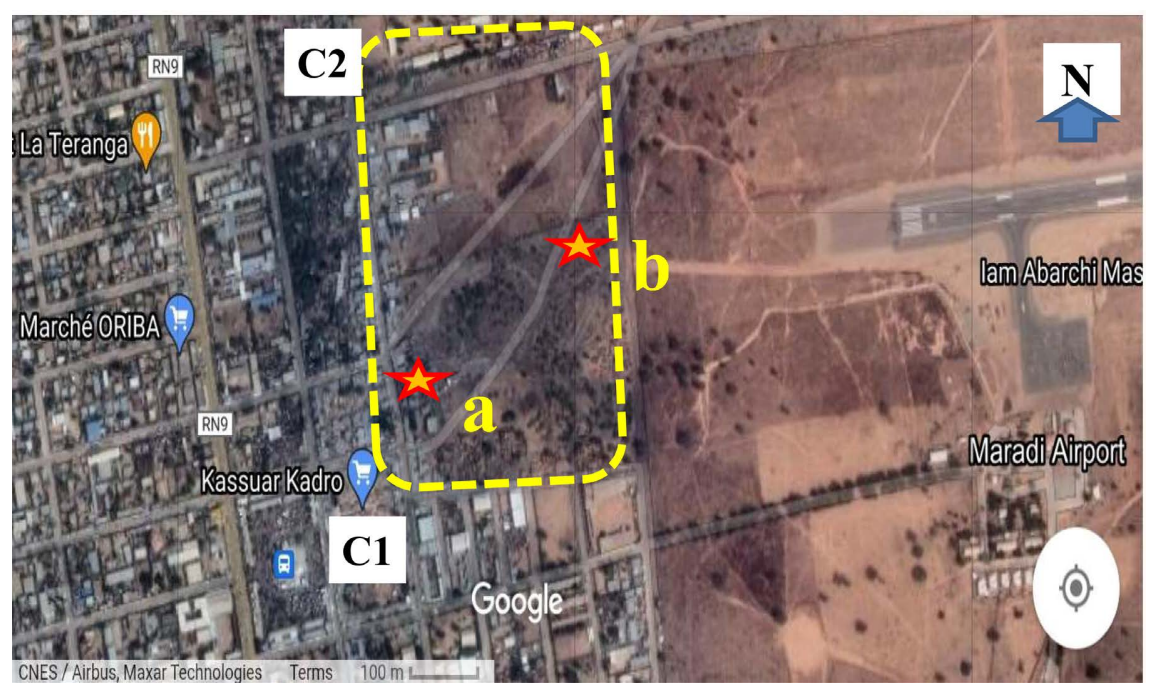

Figure 5. Random sampling area and geographical location of the photos (red yellow stars) used in the site (C). (C1): Kassuar Kadro (Kadro market) and (C2): Kadro market waste deposit (Source: Google Earth).

the number of people who provided the same response with respect to a given parameter and $\mathrm{N}$ the total number of people surveyed.

\section{Results}

\subsection{Empty Space Covered and Empty Plots Used}

Close to the city center, the Kadro market straddles municipalities 2 and 3 (Figure 1). This market is experiencing considerable economic growth with the sale of manufactured products, fruits and vegetables as the main activity. Figure 5 captures the progression dynamics of the waste deposit produced at Kadro market on the streets and wasteland to the west and north of the Maradi Airport. The Kadro waste deposit houses several important features such as: precarious dwellings, packaging waste, organic matter, poultry clearing, sugar cane peeling service (Figure 6 and Figure 7).

Figure 8 shows part of the northwest face of the Malan Hamissou Dan Taxi 


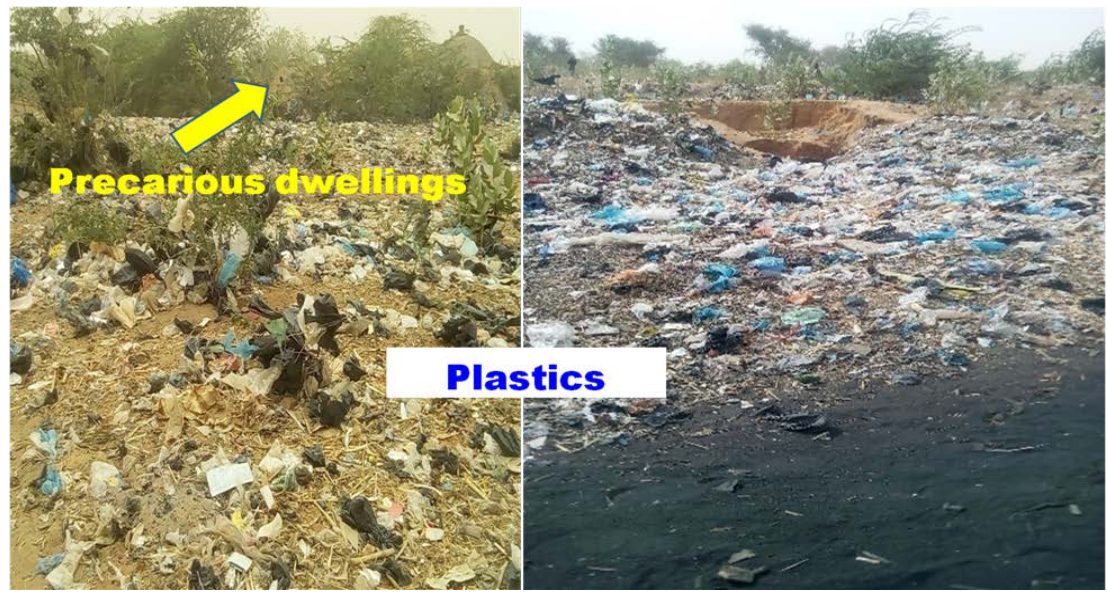

Figure 6. Precarious dwellings, plastic waste and cardboard in the Kadro deposit (C2b; Table 2 and Figure 5).

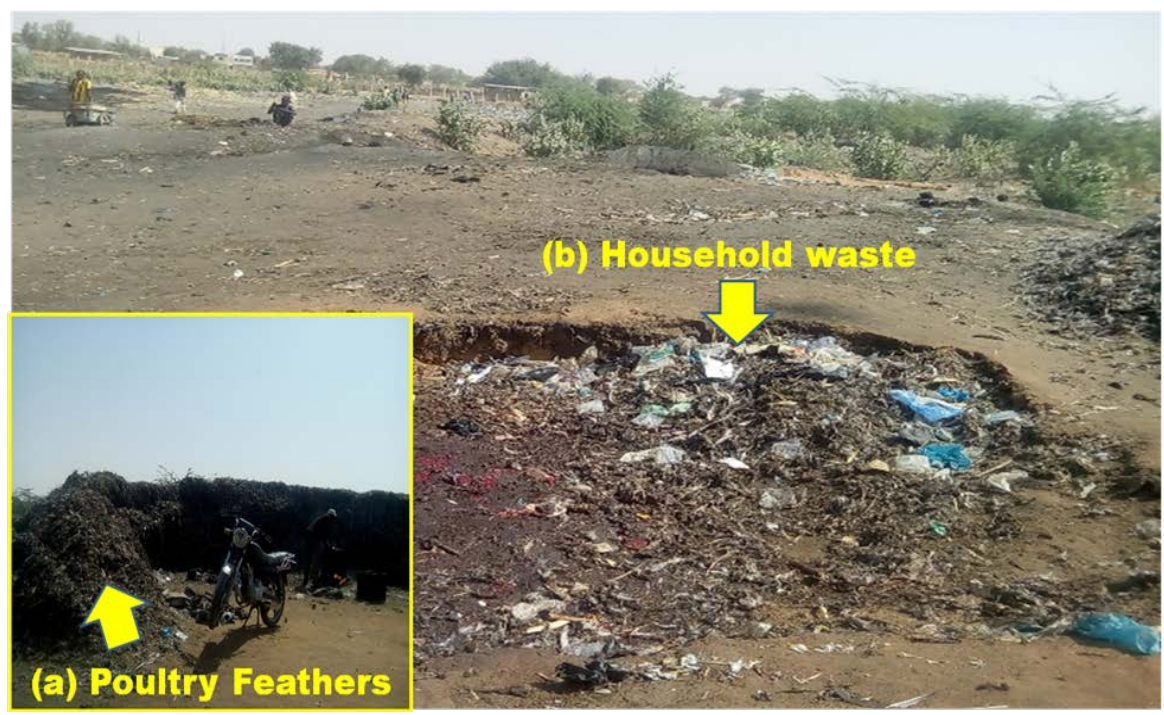

Figure 7. Poultry feathers (a) and mixed household waste (b) in the Kadro deposit (C2a; Table 2 and Figure 5).

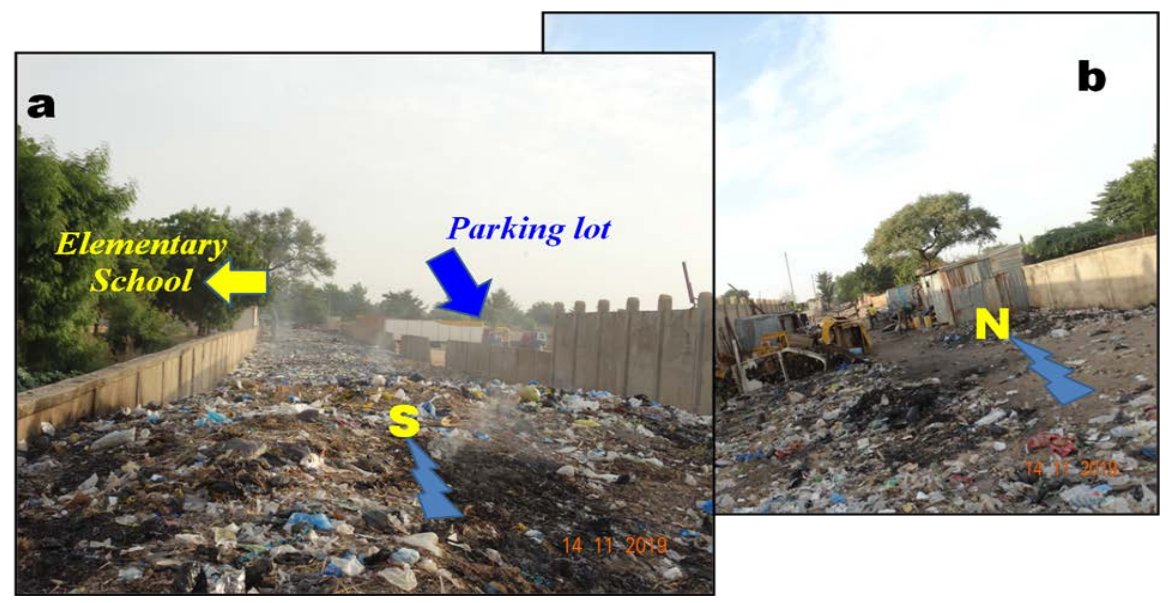

Figure 8. Southern (a) and northern (b) parts of an access road to an elementary school cut off by the waste in sector A (A2b; Table 2). 
Mosque (A2b; Table 2 and Figure 3), a road wedged between a primary school and a heavy truck parking lot carrier. Thus, in the first and second planes, there are piles of garbage resulting from uncontrolled dumping and related economic activities. Areas that emerge a few meters above the surface along the school wall are paved with dunes of rubbish, while municipal dumps are flooded with household litter (Figure 9).

As scenes in Figure 10 suggest, the congestion phenomena are also a reality in sector B and occurs in many forms. For a very long time, recourse to the filling of streets with waste has increased as the risk of flooding (Figure 10(B1b)) and the economic stakes have increased (Figure 10(B3a)). Figure 11 indicates the presence of plots transformed into crop fields and parking lots. Among the many crops, millet (Pennisetum glaucum), sorghum (Sorghum bicolor), groundnuts (Arachis hypogea), cowpea (Vigna unguiculata WL) and maize (Zea mays) are one of the most popular crops (A1a; Figure 3).

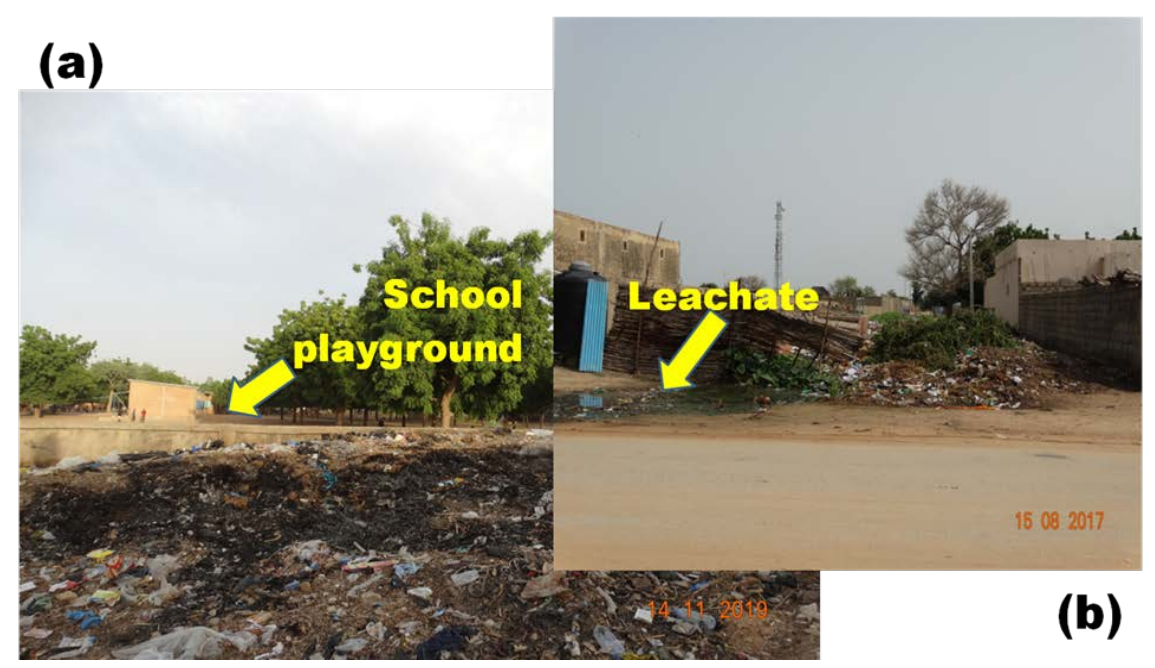

Figure 9. Elementary school playground (a: A2b) and a municipal dump scene (b: A2c) in sector A (A2; Table 2 and Figure 3). How many environmental stressors for the elementary school next door?

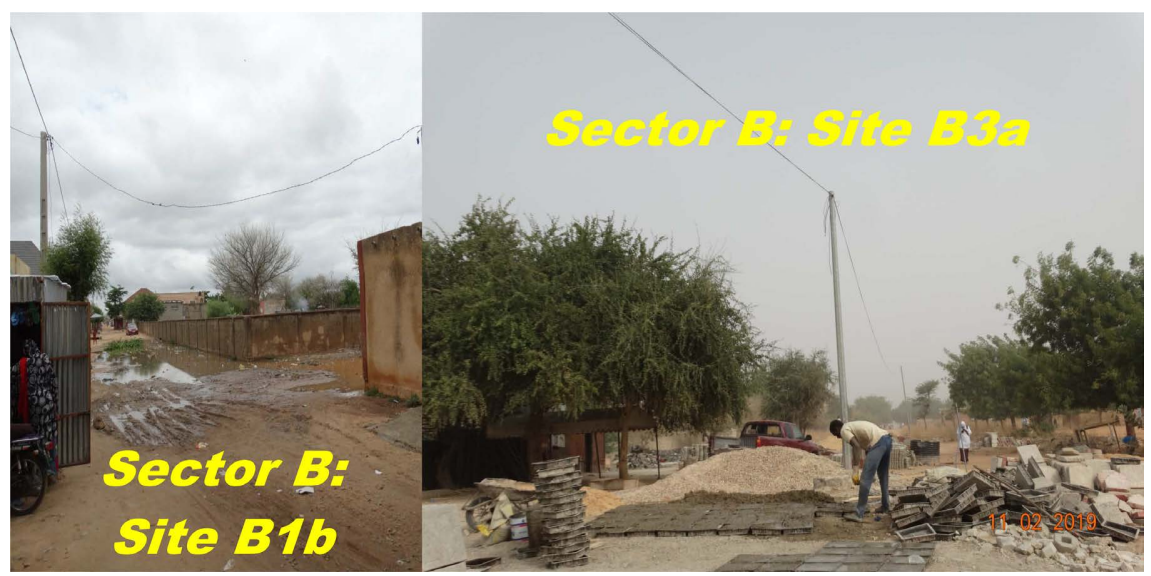

Figure 10. Scenes show that different individuals take varying actions on certain entities in or around empty space (sector B: B1b and B3a; Table 2 and Figure 4). 
Truckers use empty plots and the surrounding areas for parking (A2a; Figure 3). Due to the bumpy deformation of the terrain, "internal ponds" are created which house Batrachians with noise pollution during the rainy season. The scenes, depicted in Figure 12, suggest that more intense economic activities were carried out by empty plot inhabitants, as they worked on a set of rainy and dry seasons.

\subsection{Perceived Environmental Quality and Biodiversity Conditions}

\subsubsection{Level of Education and Occupations of Respondents}

The educational level of respondents ranges from illiterate (8.33\%) to university (circa 3\%) (Table 3). It emerges that $58.33 \%$ of those surveyed claim to have attended Koranic school, while $9 \%$ say that they have reached a level of education that goes up to secondary school compared to $22 \%$ who dropped out at primary school level. Respondents are from very diverse professions with $22.22 \%$ of heads of households engaged in household and commercial activities, circa $16.67 \%$ shopkeepers, against $8.33 \%$ and $5.55 \%$ in catering and sewing, respectively.
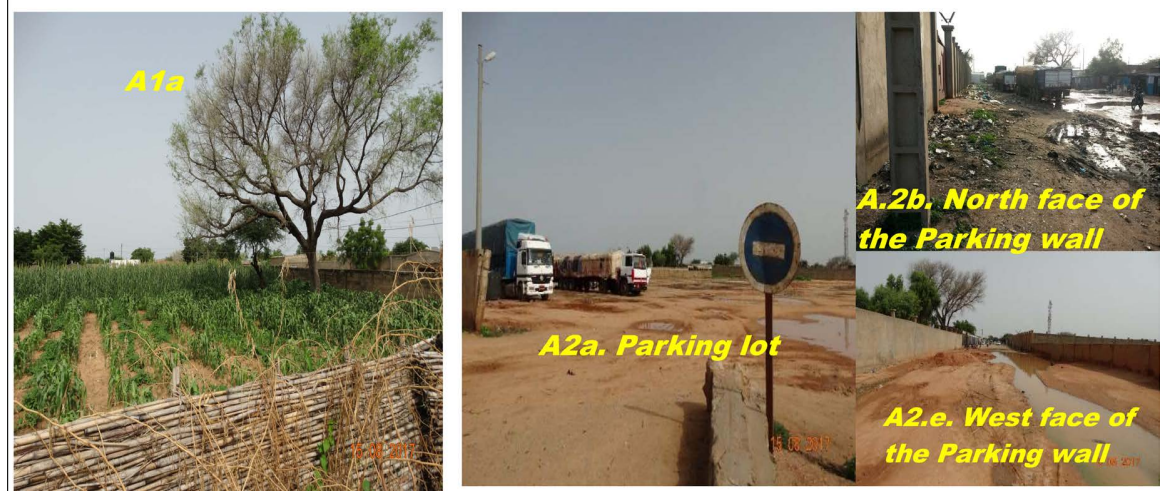

Figure 11. An illustration of the ways in which the empty plot may have a variety of space occupation forms and the consequences for the inhabitants of sector (A) at Ali Dan Sofo (Table 2 and Figure 3).

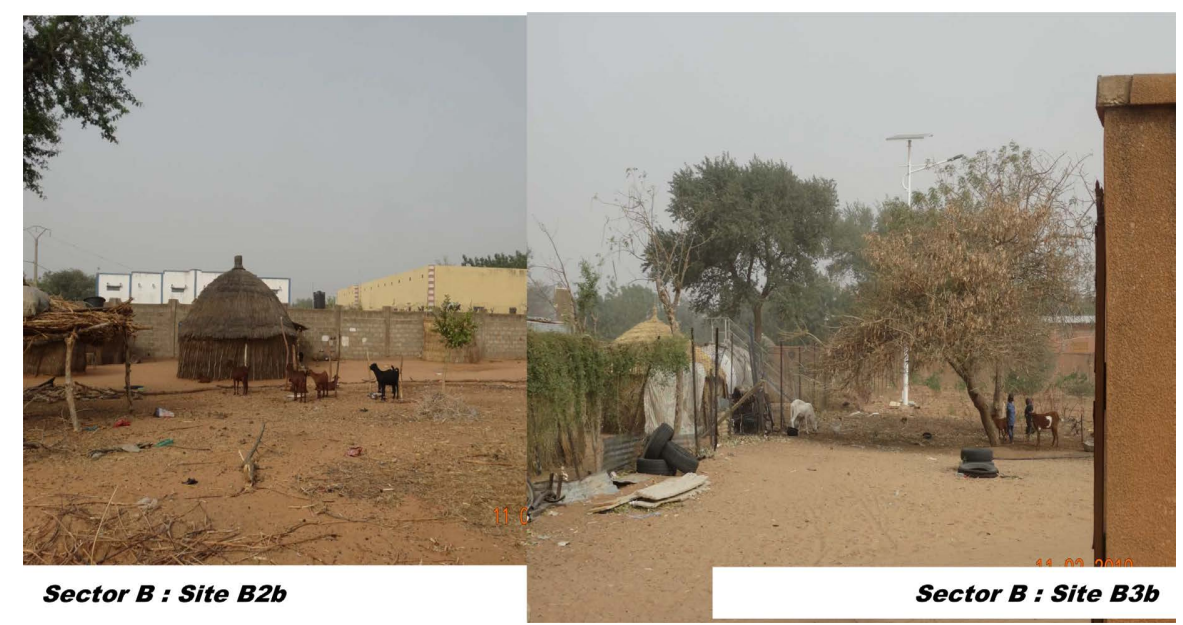

Figure 12. Breeding of small ruminants in empty plots in sector (B) (Sites B2b and B3b; Table 2 and Figure 4). 
Besides services (5.56\%), agro-pastoral products also generate jobs for respondents $(36.67 \%)$ in the field of resale (sale of poultry, grilling, frying, plants and flowers, etc.).

\subsubsection{Knowledge of the Impacts of Economic Activities and the Risks of Waste}

These respondents have a good level of knowledge of the impacts of these activities on their environment, as $69 \%$ categorize them as negative impacts and $31 \%$ as positive impacts. In addition, they can give examples of risks of waste to the environment and health (Table 4). The respondents believe that the anarchic accumulation of garbage is responsible for the proliferation of mice $(24 \%)$ and mosquitoes (17\%), the excessive presence of flies (14\%) and the invasion of

Table 3. Socio-demographic characteristics of the respondents.

\begin{tabular}{llcc}
\hline \multicolumn{2}{c}{ Socio-demographic characteristics } & Effective & Percentage (\%) \\
\hline \multirow{4}{*}{ Educational level } & Koranic studies & 21 & 58.33 \\
& Graduate studies & 1 & 2.79 \\
& Secondary & 3 & 8.33 \\
& Primary & 8 & 22.22 \\
& None & 3 & 8.33 \\
\hline \multirow{5}{*}{ Occupations } & Householder & 8 & 22.22 \\
& Shopkeepers & 6 & 16.67 \\
& Poultry clearing & 6 & 16.67 \\
& Chicken vendors & 4 & 11.12 \\
& Restoration & 3 & 8.33 \\
& Tailors & 2 & 5.55 \\
& Plants vendors & 2 & 5.55 \\
& Grills & 2 & 5.55 \\
& Gasoline dealers & 1 & 2.78 \\
& Masonry & 1 & 2.78 \\
& Farmers & 1 & 2.78 \\
\hline
\end{tabular}

Table 4. Major dimensions influencing the annoyance.

\begin{tabular}{lc}
\hline \multicolumn{1}{c}{ Risks } & Citation rate (\%) \\
\hline Ravage of mice & 24 \\
Mosquito proliferation & 17 \\
Excessive presence of flies & 14 \\
Termite damage & 14 \\
Diseases & 15 \\
Ultimate degradation of biophysical environment & 10 \\
The bites & 6
\end{tabular}


termites (14\%), that can cause: diseases (15\%), enhance the bite cases (6\%) and impact on the ground (10\%) (Figure 13). While the recurrent response to considerable waste in the repositories was an upgrading decomposition on the landfill site itself (see Figure 9), population often disposed of it by incineration (Figure 14). The main diseases caused by the anarchic accumulation of waste according to respondents are malaria (74\%) and respiratory disorders (16\%). The least cited (4\%) are gastric disorders and diarrhea (10\%). In addition to illegal dumping of garbage, the surveyed affirm that the factors which increase the risks of diseases are the lack of gutters and dumps (34\%), and as can be seen in Figure 15, the stagnation of rainwater $(27 \%)$ and the proliferation of wild plants and grass (5\%).

\subsubsection{The Setting Perception and Response to Biodiversity Conditions}

The field survey shows that the empty land contains several plant species (woody

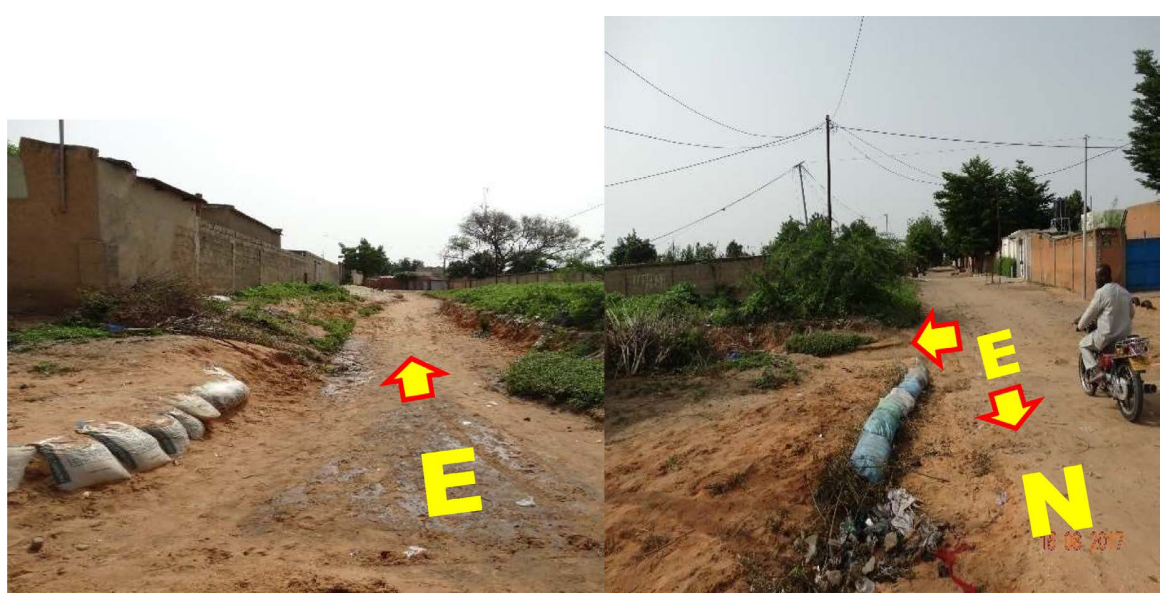

Figure 13. State of play around the edges of a neglected site in sector A (site A1b; Table 2 and Figure 3). On the left, degradation by rainwater, and on the right, some herbaceous carpet and former household waste.

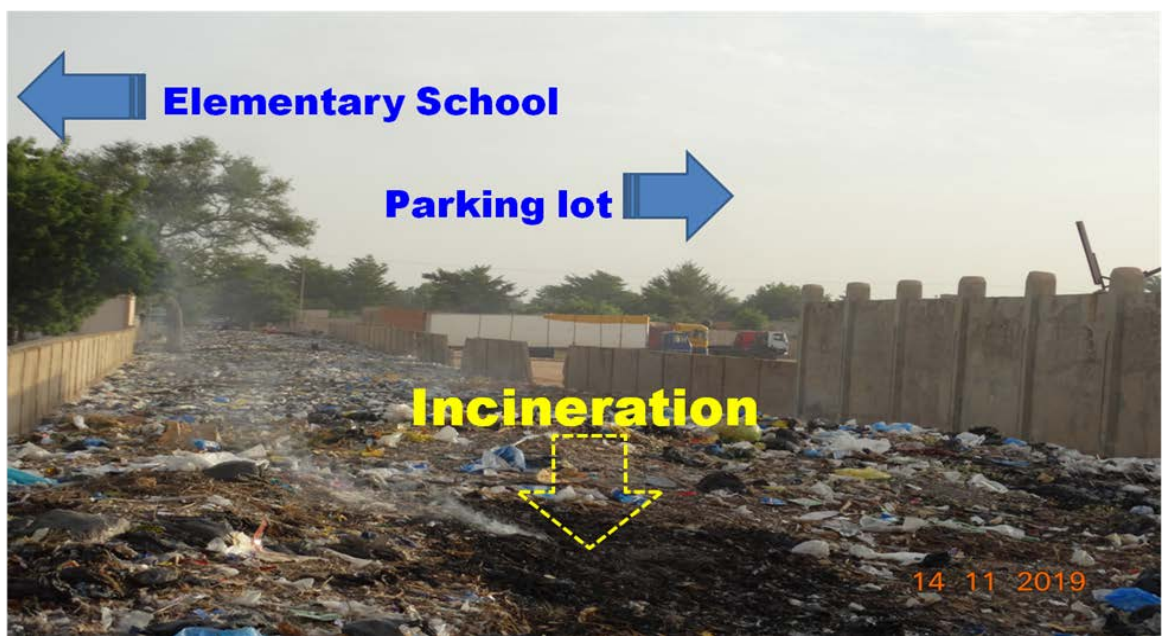

Figure 14. Irregular emptying by incineration of a deposit in sector A (site A2b; Table 2 and Figure 3). 


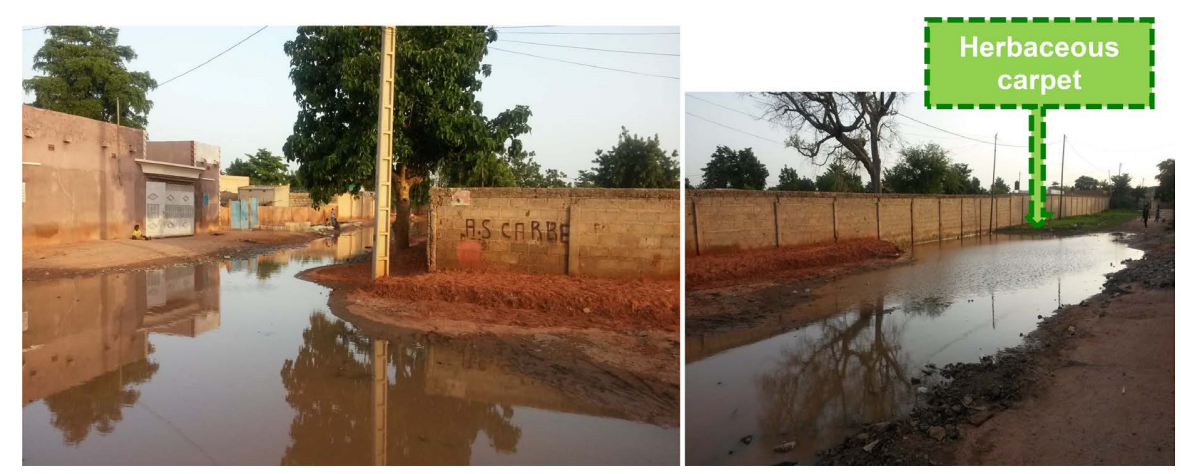

Figure 15. Flooding around houses near abandoned land in Sector A (North-East of A1a; Table 2 and Figure 3).

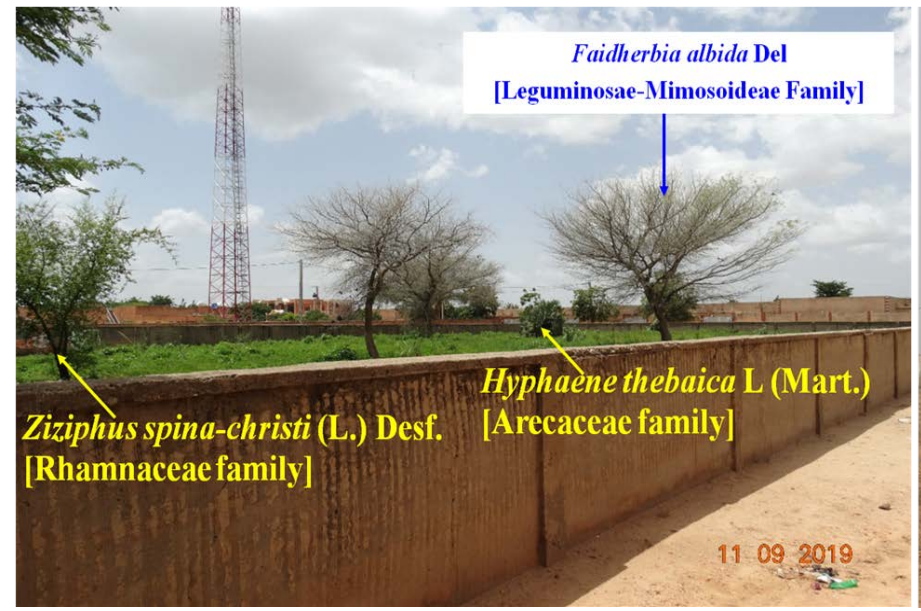

(a)

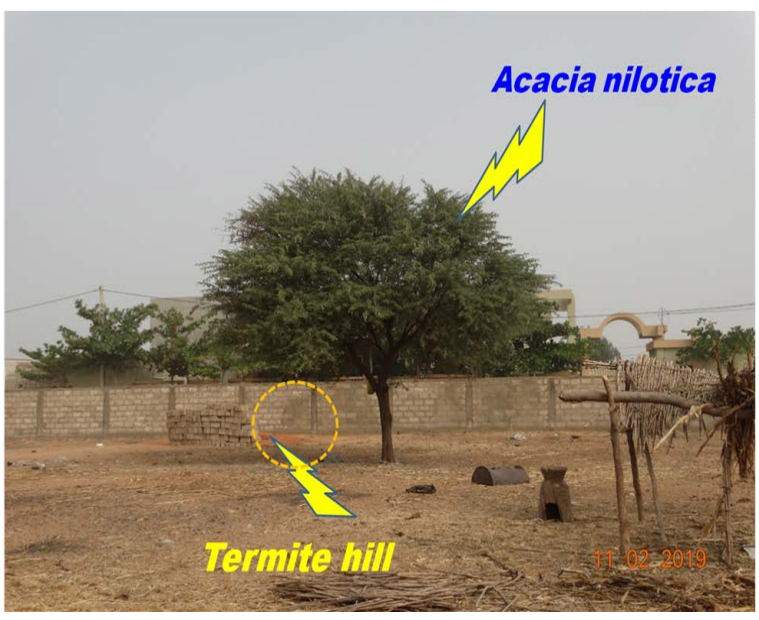

(b)

Figure 16. Example of an urban ecosystem in sector B (sites B1a and B2a; Figure 4). Some empty plots are positively labeled and desired by phone companies (Figure 16(a)). Over time, with termite mounds (Figure 16(b)), some present a relatively permeable sandy ground, and the most common Acacia nilotica is maintained for different uses (e.g., shade, fruit for the tannery, leaves and bark for medicines).

and herbaceous; Figure 16). The main species of flora and plants recorded on abandoned land taken as witnesses is stipulated in Table 5 below. It emerges from this summary inventory that the most dominant species are: Sida cordifolia L. (35\%), Prosopis juliflora (SW) DC. (15\%), Corchorus tridens L. (10\%) and Cassia mimosoïdes L. (8\%).

Table 6 presents the citation rate of dominant and niche animal species in and around empty spaces. The most represented are Culicidae $s p$ and Felis lybica, and Muridae $s p$ with $36 \%$ and $16 \%$ of daily overload and environmental stress respectively. The respondents stated that night (50\%) and rainy season $(48 \%)$ are the periods when these animals proliferate, especially mosquitoes, rats and small insects.

Table 7 reveals the different mitigation measures proposed by the respondents. Thus, $46 \%$ of those surveyed propose the contribution of garbage cans in each place where economic activities take place or in each district of the city. In addition, $19 \%$ of respondents suggest that the city hall can monitor the garbage 
Table 5. Most cited flora and plant species/families

\begin{tabular}{|c|c|c|c|}
\hline Species & Citation rate $(\%)$ & Families & Citation rate (\%) \\
\hline Sida cordifolia L. & 35 & \multirow{2}{*}{ Malvaceae } & \multirow{2}{*}{39} \\
\hline Hibiscus asper Hook. & 4 & & \\
\hline Prosopis juliflora (SW) DC. & 15 & \multirow{3}{*}{ Leguminosae-Mimosoideae } & \multirow{3}{*}{19} \\
\hline Faidherbia albida Del. & 2 & & \\
\hline Acacia nilotica (L.) Willd. & 2 & & \\
\hline Corchorus tridens $\mathrm{L}$. & 10 & Tiliaceae & 10 \\
\hline Cassia mimosoïdes $\mathrm{L}$. & 8 & \multirow{2}{*}{ Leguminosae-Caesalpinioideae } & \multirow{2}{*}{10} \\
\hline Cassia tora L. & 2 & & \\
\hline Phyllanthus pentandrus Schumach. Et Thonn. & 6 & Euphorbiaceae & 6 \\
\hline Crotalaria podocarpa DC. & 4 & \multirow{2}{*}{ Leguminosae-Papilionoideae } & \multirow{2}{*}{6} \\
\hline Alysicarpus ovalifolius (Schum. \& Thonn.) J. Leon. & 2 & & \\
\hline Calotropis procera (Ait.) Ait. F. & 3 & Asclepiadaceae & 3 \\
\hline Ziziphus spina-christi (L.) Desf. & 2 & Rhamnaceae & 2 \\
\hline Andropogon gayanus Kunth. Var. gayanus & 2 & Poaceae & 2 \\
\hline Centaurea perrottetii DC. & 2 & Compositae & 2 \\
\hline Hyphaene thebaica (L.) Mart. & 1 & Arecaceae & 1 \\
\hline
\end{tabular}

Table 6. Most cited animal species.

\begin{tabular}{cccc}
\hline Species & Citation rate (\%) & Species & Citation rate (\%) \\
\hline Culicidae $s p$ & 18 & Papillonacae $s p$ & 2 \\
Felis lybica & 18 & Hemidactylus frenatus & 2 \\
Muridae $s p$ & 16 & Chamaeleonidae $s p$ & 1 \\
Musca domestica & 14 & Erinaceldae sp & 1 \\
Crocidura russula & 9 & Cigogna nigra & 1 \\
Blattodea $s p$ & 6 & Civettictis civeta & 1 \\
Corvus corax & 3 & Bulvulcus ibis & 1 \\
Bifonidae $s p$ & 3 & Oedaleus senegalansis & 1 \\
Psammophi $s p$ & 2 & Streptopelia roseogrisea & 1 \\
\hline
\end{tabular}

Table 7. Mitigation measures proposed by the respondents.

\begin{tabular}{cccc}
\hline Mitigation measures & Citation rate (\%) & Mitigation measures & Citation rate (\%) \\
\hline Trash cans & 46 & Money collections by the locals & 3 \\
City hall supervision & 19 & Servicing places & 3 \\
Reliable places for deposits & 8 & Recovering waste & 3 \\
Gutters & 5 & Defend agricultural activities in neighborhoods & 2 \\
Sensitization & 5 & Make compost from feathers (Kadro deposits) & \\
Make fines & 3 & & \\
\hline
\end{tabular}


cans from time to time and 5\% suggest the support from the authorities in reliable places for good functioning activities (e.g., ordering to maintain empty plots clean). As it happens into some clean empty plots, nearly all of the termite mounds can be specific conduits for water infiltration (Figure 16(b)).

\section{Discussion}

While the tolerant trivialization of the empty plots is good for some people and bad for others, and optimal for some activities but not for the physical environment. The ultimate water source and sink problems are uncontrolled crowding of the younger generation of traders and the crowded streets. These results are comparable to those of other works carried out by [30] in the agglomeration of Souk-Ahras in Algeria, and by [31] in the city of San-Pedro in Côte d'Ivoire.

The reality on the ground shows that the non-built plots, by their owners constitute wild deposits of various wastes. While wild dumps continued to accumulate around empty plots, agricultural practices in these city plots, as well as the flora and fauna favored there, contribute to the visual degradation of the environment, pollution and nuisances. This is the case for inhabitants, who dwell close to wild deposits, who undergo the ordeal of cockroaches during the night [12], and that of mice and rats which turn into real invaders out of the rubbish heaps [32].

Beyond these reasons, respondents have contributed to two major ideas. Firstly, the attractiveness of garbage on certain fauna and flora species is the source of many diseases such as malaria, as well as the proliferation of stray dogs, rodents, insects and birds [33]. Secondly, the waste diffusion and appearance of plant species also exacerbate scarcity or even extinction elements of the flora useful for the human population and animals (medicinal plants, plants used as pasture, trees used as nesting boxes for birds, etc.). As [34] points out, some plants can assimilate toxic substances from this waste and transmit them to animals that are consumed by humans. Consequently, the waste disposal environments can become favorable grounds for the proliferation of the cryptogamous flora and the population that comes to collect these plants can be infected by the waste.

Burning waste produces larger amounts of particle matter and fly ash. The most threatening product of waste-burning activities are particles of toxic metals (e.g., $\mathrm{Hg}, \mathrm{Pb}, \mathrm{Fe}, \mathrm{Cu}, \mathrm{Cr}, \mathrm{Ni}, \mathrm{Cd}, \ldots$; [21]) which could contaminate the grounds and the people of the neighboring school (Figure 8, Figure 9 and Figure 14). This practice, like the croaking of toads in ponds in the truck parking lot (Figure 11), does not comply with Article 74 [14] which prohibits the emission of noise and odors that may harm human health, to constitute an excessive embarrassment for the neighborhood or to damage the environment. The people behind these emissions, as well as the owners of empty plots, must take all necessary steps to remove them.

Furthermore, the leachate mediates between waste water, rainwater and runoff crossed the landfill (Figure 8, Figure 9 and Figure 14). The relevance of 
this can be seen as a key to an overall understanding of the interaction between human activities, soil and groundwater. Furthermore, growing evidence indicates that in the city of Maradi, informal economic activities are more frequent during the rainy season (53\% of respondents; [19]). Thus, the evolution of seasonal rhythms suggests that the climate is the main determinant of the diet of the population and, consequently, influences the production of waste in the environment. Roughly, a source of more extending waste problems would begin with water throughput and the reduction of infiltration. To corroborate this idea, [1] consistently found that all waterproofed surfaces (roads and car parks) are relevant to carbon destocking in the soils, and that they are probably other ways of conceptualizing the majority use of the car and more energy mobilization.

This evidence has profound implications for understanding and addressing the current piles of uncollected garbage and decomposing wild deposits (Figure 9 and Figure 14). In many cases, those are also responsible for poor drainage in the region by preventing the correct evacuation of rainwater [35]. With the same basic assumptions, the results obtained by the present study are consistent with those of [32] in the city of Porto-Novo (Benin) and [36] in the city of M'Bahiakro in Côte d'Ivoire.

Overall, the flooding around houses near empty plots (Figure 10 and Figure 15) increases the disfigurement of the neighborhood (Figure 13). The drainage problems undoubtedly reinforce the phenomenon of erosion in the study environment. In support of this result, [37] also found that the nature of the soil, like precipitation and slope systems, is a determining factor in rainfall erosion in the city of Adjarra in Benin. Additionally, erosion phenomena leave remarkable sections of the land (e.g., herbaceous carpet; Figure 13) to escape rain erosion. Those non-significant stripping levels are areas that benefit from a special arrangement or a measure of protection by invasive species. In spite of these visual degradation of the environment and different multiplication conditions of certain diseases, the flora contributes to soil protection and grazing. In other words, the criteria for dealing with such problems are in the values that guide its management, in terms of consensus on the protection parameters.

At least the advantage of abandoned land is that "empty" spaces emerge as the last vestiges of urban biodiversity (Figure 16). Under these ecological conditions, the development and distribution of the flora are linked to pollination by the wind which carries the pollens, as well as to the conservation of seeds in the edaphic substrate of these soils. Additionally, field observations advocated that such undeveloped land is a favorable environment for wildlife by creating an important source of food webs entering nearby houses (Figure 7). This is in accordance with the findings of [1] study that reported that "Talking about biodiversity in the city may seem paradoxical. However, if urbanization is a source of biodiversity loss due to the areas occupied by housing, roads (...), it can also maintain it, either by preserving specific habitats (brownfields, wetlands (...), Parks and gardens, ...), either by the large landscape mosaic of the urban and 
periurban areas, or by the introduction, voluntary or not, of exogenous species (...)".

Still, it is clear that the regeneration of flora in empty plots stems mainly from the tolerance of the inhabitants towards pioneer wild species that evolves over time. Food security is crucial if we expect people, who are denied access to basic resources, to continue to struggle against in order to alleviate poverty. Counterintuitive, as rural population migration grows, the empty plots have a better factual demand from low-income families (Figure 5). Many of these migrants find shelter in the empty plots. Consequently, these people contribute to the improvement of the quality of life of the residents through their participation in financial activities (e.g., field work, market gardening, baby seating and domestic work; Figure 11 and Figure 12) which develop there. In fact, undeveloped land can have a positive impact on food security, in addition to the fact that they can contribute to the fight against poverty. In addition to the usefulness of plant regeneration in empty plots, the sandy nature and the maintenance of some of them (Figure 16(b)) contrast with the capacity of these areas to be privileged areas for a "clean" recharge of urban aquifers.

The identification and citation of the mitigation measures presented in Table 7 make it possible to draw unequivocal conclusions about their impacts on the determinants of urban insalubrity. It is the bins and public dumps that are the most involved. In other words, the installation of these containers and their surveillance by the authorities (19\% of respondents) should promote the cleanliness of the premises and the sector under study; but, this is not the case (Figure 8). Particularly, low sensitivity (5\% of respondents) to any form of practices degrading environment may refer to the whole extreme vulnerability of population to natural risk problems in the study area. To this end, [22] revealed that the population is partly responsible for the unhealthiness in the city of Maradi. For these authors, the adoption of malpractice management and the routinely discharged in the street gutters if they exist or even in the courtyard of the concession, in which they live, characterize the behavior of residents regardless of their level of education. Thus, changing the way we look at empty spaces and any sanitation or road works remains one of the rooms for maneuver to mitigate or compensate the effects and the impacts of our practices on the environment. In fact, countermeasures will be all more useful if we take into account traditional structures (equipment and tools for maintaining sanitation) and series of indirect approaches in the field. These include awareness-raising and the strong state support for all forms of local organizations.

As [7] reports, in order to enhance the naturalness of the neglected and improve their representation, "it is not about accepting nature, it is about making it acceptable". Several conditions are therefore necessary: 1) adapting to risks, environments (slope, soil, plant cover) and types of nuisances and urban pollution, 2) enhancing the complementarities of agriculture, habitat, and livestock services by promoting early crops in the plots. Finally, these authors recommend the cul- 
tivation and the maintenance of fruit trees and legumes directly influence the risks associated with runoff and urban biodiversity. According to [38], it is also possible to intervene at several levels. The two most classic methods are urban renewal and brownfield redevelopment. But, as the saying goes, "prevention is better than cure"! That is to say, it is better to fight against the consequences upstream, by initiating and managing good practices. In relation to the perceptions expressed by the respondents and the reality on the ground, neighborhoodoriented social networking remains one of the least expensive strategies. Thus, the specific points contributing to the integrated management of a site are part of an intrinsic change of approach with regard to the "wild" nature of the abandoned urban areas [39].

Monitoring and any development of co-produced territories should contribute to the fight against unhealthy urban environments [38]. In the same way, [39] goes into more details and noted that these territories, provided they are made sustainable, could ultimately constitute real vectors for the involvement of residents in the management of local spaces. Overall, the generalization of ecogestures (e.g., make compost from feathers) and measures promoting respect for the environment and the protection of urban biodiversity make shared spaces viable tools for mediating and disseminating "good practices" in terms of sustainability and environmental efficiency [40].

\section{Conclusions}

The present work is motivated by the observation of the extent of the consequences generated by the uncontrolled landfills in the city of Maradi (Niger), in particular in the empty plots of communes 2 and 3. Waste proliferation along with unformal economic activities in these places, poses more and more the problem of urban waste management, pollution and nuisances as well as the degradation of the environment. The streets providing access to certain essential services, soils and homes are invaded and sometimes devastated by runoffs. Under the current environmental conditions, the whole population, with the exception of some of the privileged, is under very high annoyance stress.

The results of the present study showed that the severity of the effects is related to several factors. These include, among others, the development of wild flora and fauna, as well as the prevalence of seasonal diseases. In addition this is the inadequacy of garbage disposal methods, the most common of which are incineration and in situ decomposition. In fact, these various waste treatment processes are the basis of the residues responsible for the emission of polluting fumes into the air and the pollution of groundwater by various contaminants.

These results also showed that wastelands and other empty plots constitute the last vestiges and privileged places for a certain urban biodiversity. Grass mats, adjacent to the walls of empty plots, increase the importance of protective measures against soil erosion. Interestingly, besides the nuisances, we must also notice the contribution of empty plots to income increase, the fight against po- 
verty and also carbon dioxide $\left(\mathrm{CO}_{2}\right)$ emissions. It is undeniable that the empty plots constitute a city within a city without which many residents would find themselves in slums. This should particularly attract the attention of decision makers, who must take measures and carry out actions aimed at limiting the constraints to protect the environment in a sustainable manner.

\section{Acknowledgements}

The authors are grateful to Mrs. Ikilima Elh. Yaou Mamane and Mrs. Jamila Laouali Ousmane for assisting with the selection of fieldwork areas. We express our gratitude du Dr Yacoubou Alou for his untimely proofreading and correcting the manuscript.

\section{Data Accessibility}

Data will be made available upon request.

\section{Conflicts of Interest}

The authors declare no conflicts of interest regarding the publication of this paper.

\section{References}

[1] Desailly, B., Béringuier, Ph., Briane, G. and Dejoux, J.-F. (2009) Les Impacts Environnementaux de l'étalement Urbain. Perspectives Ville, halshs-00914585.

[2] Diomande, B.I., Dia Hantchi, K. and Gbalou, D.S.J. (2017) État de la déforestation, incidences climatiques et socio-économiques dans la commune de Bouaké en Côte d'Ivoire. Annales de l'Université Abdou Moumouni de Niamey, XXII-A, 87-101.

[3] Redjal, O. (2005) Vers un développement durable, phénomène de prolifération des déchets urbains et stratégie de préservation de l'écosystème-Exemple de Constantine. Mémoire de Magister, Université de Mentouri, Mentouri (Algérie).

[4] Vernier, J. (2011) L'environnement. Que sais-je? 10th Edition, France No 2667, Presses Universitaires de France, Paris. http://www.quesais-je.com

[5] Massouangui Kifouala, M. (2019) Vulnérabilité du site urbain de Brazzaville (République du Congo) face à la menace climatique et à la pression démographique. Afrique Science, 15, 206-217.

[6] Arce, S. (2009) Conservation de la biodiversité en milieu urbain: considérations écologiques et analyse du cas de Montréal. M.Sc. Thesis, Université du Québec à Montréal, Montréal.

[7] Brun, M., Vaseux, L., Martouz, D. and Di Pietro, F. (2017) Usages et représentations des délaissés urbains, supports de services écosystémiques culturels en ville. Environnement Urbain/Urban Environment, 11.

http://journals.openedition.org/eue/1906 https://doi.org/10.7202/1050493ar

[8] Sambieni, K.R., Bilosso Moyene, A., Toyi, M.S., Sambieni, E., Natta, A.K., Occhiuto, R. and Bogaert, J. (2018) La biodiversité des parcelles habitées en zone périurbaine à Kinshasa: déterminants socio-biophysiques et représentations. International Journal of Biological and Chemical Sciences, 12, 1164-1183. https://doi.org/10.4314/ijbcs.v12i3.8 
[9] Issaka, H. Moussa, S., Moussa, D.D. and Yamba, B. (1998) Étude sur les pollutions et nuisances. Cas de Niamey, Tahoua-Maradi et Zinder. Rapport provisoire, République du Niger/Programme des Nations Unis pour le Développement (PNUD), Niamey (Niger).

[10] Tini, A. (2003) La gestion des déchets solides ménagers à Niamey au Niger. Essai pour une stratégie de gestion durable. Ph.D. Thesis, Institut National de Lyon, Lyon.

[11] Moussa, O. (2016) Les déchets plastiques: Un casse-tête pour notre environnement. ONEP (Niger). Le vendredi.

https://www.nigerdiaspora.net/Archives-Nigerdiaspora-2003-2020/index.php/envir onnement-archives/item/76178-les-dechets-plastiques-un-casse-tete-pour-notre-en vironnement

[12] Abdourahamane Illiassou, S., Amadou Oumani, A., Abdou, L., Mahamane, A. and Saadou, M. (2016) Urban Biodiversity: Perception, Preference, General Awareness, and Threats in Two Cities (Niamey and Maradi) of Niger. Urban Studies Research, 2016, Article ID: 1469530. https://doi.org/10.1155/2016/1469530

[13] Mamadou, I. (2015) Colmatage des mares et risques environnementaux dans la ville de Zinder. Master Thesis, Université de Zinder, Zinder (Niger).

[14] République du Niger (1998) Code de l'environnement du Niger: Loi N98-56 du 29 décembre 1998 portant Loi-Cadre relative à la gestion de l'environnement, Niamey (Niger).

[15] Nouhou, I. (2010) Les effets des marchés fonciers et expropriations des terres dans la ville de Zinder au Niger. Mémoire de DEA, Université Abdou Moumouni, Niamey.

[16] INS (Institut National de Statistique) (2016) Statistique de l'éducation de base et alphabétisation 2015-2016. République du Niger.

[17] Saidou, I. (2014) Maradi, ville commerçante. Le Sahel Niger.

[18] Grégoire, E. (1986) Les Alhazai de Maradi (Niger): Histoire d'un groupe de riches marchands sahéliens. Travaux et Documents de I ORSTOM, 187, ORSTOM, Paris.

[19] Elh Yaou Mamane, I. and Laouali Ousmane, J. (2019) Ampleur et impact de la dégradation des milieux urbains par les déchets des activités économiques: cas de la ville de Maradi. Mémoire de Licence Professionnelle EIE, Université Dan Dicko Dankoulodo, Maradi (Niger).

[20] Mamadou Beido, A. (2013) Impact positif et moyenne contamination par les métaux lourds des sols de sites de stockage des déchets. Cas de la ville de Maradi (Niger). M.Sc. Thesis, Université Dan Dicko Dankoulodo, Maradi (Niger).

[21] Abdourahamane Illiassou, S., Manzo, O.L., Djima, I.T., Beido, M.A.A., Saidou, I.S., Moussa, M.B., Mahamane, A. and Saadou, M. (2015) Impact of Solid Waste Disposal System on Soil in Maradi City (Niger Republic): A Preliminary Study of Heavy Metal Contamination. International Journal of Current Microbiology and Applied Sciences, 4, 650-659.

[22] Laminou Manzo, O., Saidou, H., Abdourahamane Illiassou, S. and Tidjani Idrissa, S. (2015) Assessment of Domestic Wastewater Management Practices in the Communal District I of Maradi City, Niger Republic. Journal of Geoscience and Environment Protection, 3, 57-65. https://doi.org/10.4236/gep.2015.38006 https://www.scirp.org/pdf/GEP 2015102014220970.pdf

[23] Saidou, H. and Aminou, S. (2015) Solid Waste Management in the Town of Maradi in Niger Republic. Journal of Environmental Protection, 6, 359-373. https://doi.org/10.4236/jep.2015.64036 
[24] Issoufou Gonda, D. (2018) Gestion des déchets solides ménagers à Maradi. Mémoire de licence professionnelle EIE, Université Dan Dicko Dan Koulodo, Maradi (Niger).

[25] CUM (Communauté Urbaine de Maradi) (2013) Plan de développement communal de la commune urbaine de Maradi, Communauté Urbaine de Maradi, Niger.

[26] TCN (Trading Company of Niger) (2009) Impact Assessment Environmental Report of Tannery of Maradi. Trading Company of Niger, Maradi-Niger, 138 p.

[27] Houessionon, M.G.K., Basu, N., Bouland, C., Kedote, N.M., Fayomi, B., Fobil, N.J. and Ouendo, E.-M. (2021) Knowledge, Practices, and Environmental and Occupational Health Risks Associated with Electronic Waste Recycling in Cotonou, Benin. Occupational Diseases and Environmental Medicine, 9, 33-48.

https://doi.org/10.4236/odem.2021.92004

[28] Lee, B. (1999) Pragmatics of Community Organization. 3rd Edition, Common Act Press Canada, Ontario (Canada).

[29] Seastrom, M. (2001) Taux de réponse comme outil de gestion de la qualité des données. Recueils du symposium de statistique de Canada, Statistique Canada, Ottawa.

[30] Ababsia, M. and Ouaali, N. (2013) Vers un développement urbain durable. Phénomène de prolifération des déchets solides et stratégies de prévention de l'écosystème. Exemple de l'agglomération de Souk-Ahras Algérie. Mémoire de Master, Université Mohamed Echerif Messaadia Souk-Ahras, Algérie.

[31] Brou, H.S., Kassi, K.J.C. and Fofana, L.(2018) Les impacts environnementaux liés à la gestion des déchets solides ménagers à San-Pedro. Revue ivoirine de Géographie des Savanes, 4, 215-228.

[32] Dansou, B.S. and Odoulami, L. (2017) Enjeux environnementaux des stratégies de gestion des déchets dans la ville de Port-Novo au Sud Bénin. Revue Ivoirienne des Sciences et Technologie, 30, 138-159.

[33] Fielder, H.M.P., Poon-King, C.M., Palmer, S.R., Moss, N. and Coleman, G. (2000) Assessement of Impact on Health of Residents Living Near the Nanty-Gwyddon Landfill Site: Retrospective Analysis. BMJ, 320, 19-23. https://doi.org/10.1136/bmj.320.7226.19

[34] Zaafour, M. (2012) Impacts des décharges sauvages sur les zones humides de la région d'El-Tarf. Mémoire de DEUA, Université de Bordj-Mokhtar Annaba, Tunisie.

[35] Hassidou, S. and Moustapha, L.A.M. (2015) Management of Urban Wastewater in the City of Maradi (Niger): The Case of Domestic Wastewater. Journal of Geoscience and Environment Protection, 3, 25-34. https://doi.org/10.4236/gep.2015.33003

[36] Diarrassouba, B., Vein, K.N. and Kouakou, K.S.E. (2018) Assainissement liquide et pluvial en milieu urbain: Etat des lieux et perspectives à M'Bahiakro (Côte d'Ivoire). Revue ivoirine de Géographie des Savanes, 4, 229-245.

[37] Etene, C.G., Issa, M.S., Chabi, P.A.B., Koussinou, E. and Soukossi, R. (2017) Érosion pluviale et dégradation des établissements humains à Adjara au Bénin. Revue Ivoirienne des Sciences et Technologie, 30, 217-234.

[38] Bell, P.A., Fischer, J.D., Baum, A. and Greene, T.C. (1990) Environmental Psychology. 3rd Edition, Harcourt Brace Jovanovich College Publishers, Orlando (Florida, USA), $637 \mathrm{p}$.

[39] Demailly, K.E. (2011) Les délaissés urbains: Supports d'une participation citoyenne constitutive de nouveaux territoires? Le cas des jardins partagés de l'est parisien. Communication à la Deuxième journée doctorale sur la participation du public et la démocratie participative, École des Hautes Études en Sciences Sociales, Paris. 
https://www.participation-et-democratie.fr/les-delaisses-urbains-supports-d-une-pa rticipation-citoyenne-constitutive-de-nouveaux-territoires

[40] Demailly, K.E. (2018) Les jardins partagés franciliens. Géographie et cultures, 101, 79-95. http://journals.openedition.org/gc/4916

https://doi.org/10.4000/gc.4916 